\title{
TINGKAT KECEMASAN DAN TEKANAN DARAH SELAMA PRAKTIK DAN SEBELUM UJIAN PRAKTIK DI LABORATORIUM PADA MAHASISWA TINGKAT 1 PROGRAM STUDI KEPERAWATAN TASIKMALAYA
}

\author{
Sofia Februanti ${ }^{1}$, Dudi Hartono ${ }^{2}$ \\ ${ }^{1,2}$ Dosen Jurusan Keperawatan Poltekkes Kemenkes Tasikmalaya
}

\begin{abstract}
ABSTRAK
Salah satu cara untuk meningkatkan keterampilan mahasiswa keperawatan adalah ujian praktik di laboratorium. Namun, hal ini dapat menyebabkan kecemasan bagi mahasiswa sebelum melaksanakan ujian tersebut. Penelitian ini bertujuan untuk mengidentifikasi gambaran tingkat kecemasan dan hasil pengukuran tekanan darah mahasiswa tingkat I Program Studi Keperawatan Tasikmalaya selama praktik di laboratorium dan sebelum melaksanakan ujian praktik KDM di laboratorium. Desain yang digunakan adalah penelitian kuantitatif dengan rancangan penelitian deskriptif. Pengambilan sampel menggunakan teknik total sampling, dengan jumlah sampel 80 responden. Analisis data menggunakan analisis univariat. Hasil penelitian menunjukkan bahwa TD systole mahasiswa selama praktik KDM adalah 110.23 s.d. 116.27, diastole mahasiswa selama praktik KDM adalah 73.07 s.d. 76.68 . Systole mahasiswa sebelum ujian praktik KDM adalah 114.06 s.d. 119.44, diastole mahasiswa sebelum ujian praktik KDM adalah 74.37 s.d. 78.63 . Tingkat kecemasan selama praktik KDM di laboratorium berada pada tingkat kecemasan berat sebanyak 58 orang $(72.5 \%)$. Tingkat kecemasan sebelum ujian praktik KDM di laboratorium berada pada tingkat kecemasan berat sebanyak 67 orang $(83.75 \%)$.
\end{abstract}

Kata kunci: tingkat kecemasan. Tekanan darah, praktik KDM di laboratorium, ujian praktik

\section{PENDAHULUAN}

Pendidikan D III Keperawatan merupakan lembaga pendidikan yang dituntut untuk menghasilkan tenaga keperawatan yang memiliki pengetahuan, keterampilan dan sikap profesional untuk memenuhi kebutuhan masyarakat akan pelayanan kesehatan bermutu, khususnya pelayanan keperawatan. Salah satu cara untuk meningkatkan keterampilan mahasiswa keperawatan adalah ujian praktik di laboratorium. Namun, hal ini dapat menyebabkan kecemasan bagi mahasiswa sebelum melaksanakan ujian tersebut. Cemas merupakan salah satu respon yang sering dialami oleh manusia, termasuk mahasiswa.

Kecemasan merupakan gejala normal pada manusia namun dapat berubah menjadi patologis jika gejalanya menetap sehingga mengganggu kehidupan seseorang pada jangka waktu tertentu. Kecemasan adalah kebingungan, kekhawatiran pada sesuatu yang akan terjadi dengan penyebab yang tidak jelas dan dihubungkan dengan perasaan tidak menentu dan tidak berdaya (Suliswati, 2005). Mahasiswa rentan mengalami kecemasan baik ringan atau bahkan sampai sedang. Penyebab cemas tersebut diantaranya perubahan lingkungan belajar (Widosari, 2010).

Lingkungan belajar mahasiswa tingkat I secara umum berubah dari tingkat SMU ke tingkat pendidikan D III Keperawatan. Mahasiswa banyak dituntut untuk terampil melakukan suatu tindakan keperawatan, selain diperlukan juga tingkat kognitif dan afektifnya. Namun perubahan tersebut dapat menimbulkan kecemasan bagi mahasiswa jika dia tidak siap mengikuti perubahan 
tersebut. Hal ini dapat menyebabkan kebingungan dan perubahan persepsi seseorang. Perubahan persepsi ini dapat menyebabkan penurunan kemampuan memusatkan perhatian, menurunkan daya ingat seseorang, mengganggu kemampuan menurunkan menghubungan satu hal dengan hal yang lain (Kaplan dan Saddock, 2005 dalam Widosari, 2010). Ujian langsung yang berhadapan antara penguji dan teruji juga bisa meningkatkan kecemasan (Stowell \& Bennett, 2010). Mahasiswa berubah menjadi grogi, bahkan lupa terhadap apa yang telah dipelajarinya walaupun persiapan melaksanakan ujian telah dilakukan.

Pengalaman seseorang dalam melaksanakan ujian juga merupakan faktor lain dalam yang dapat mempengaruhi kemampuan belajar mahasiswa. Mahasiswa yang pernah mengikuti ujian sebelumnya, cenderung mampu melakukan ujian berikutnya dengan baik (Chamberlain, Daly, Spalding, 2011). Hal ini dapat meningkatkan hasil atau prestasi belajar mahasiswa. Faktor lain yang dapat mempengaruhi keberhasilan akademis mahasiswa secara langsung adalah tingkat kepercayaan diri dan hasil uji kecemasan dapat berdampak secara langsung (Abdi,H.M.; Bageri,S.; Shoghi,S; goodarzi,Sh.; Hosseinzadeh,A, 2012).

\section{METODE PENELITIAN}

Penelitian ini menggunakan rancangan penelitian kuantitatif. Rancangan yang digunakan adalah rancangan penelitian deskriptif. Penelitian ini bertujuan untuk mengetahui gambaran tingkat kecemasan dan hasil pengukuran tekanan darah mahasiswa tingkat I Program Studi Keperawatan Tasikmalaya selama praktik di laboratorium dan sebelum melaksanakan ujian praktik di laboratorium.

\section{HASIL PENELITIAN}

Pada tabel 1. hasil analisis didapatkan rerata umur mahasiswa adalah 18.33 tahun (95\% Cl: 18.18 - 18.47), dengan standar deviasi 0.671 tahun. Umur termuda 17 tahun dan umur tertua 20 tahun.
Dampak secara fisik pada mahasiswa ketika menghadapi stress adalah perubahan hemodinamik pada tubuh mahasiswa. Perubahan hemodinamik pada tubuh yang stress karena cemas diantaranya peningkatan tekanan darah, nadi, respirasi. Hasil penelitian Anandarajan et all (2013) memperlihatkan bahwa mahasiswa yang akan melaksanakan ujian menunjukkan peningkatan tekanan darah baik sistol maupun diastole dan nadi. Kesulitan tidur, mudah terserang penyakit, kehidupan yang penuh stress, merupakan gejala psikosomatis yang sering dikeluhkan saat mengalami stress. Hal ini menyebabkan individu tersebut mengalami kesulitan dalam mengingat, berkonsentrasi, menerima informasi saat belajar dan melaksanakan ujian (Mohler, 2013). Hasil penelitian Gaya et all (2014) menyatakan bahwa serum prolaktin dan tekanan darah mahasiswa yang sedang ujian meningkat. Hal ini berkaitan dengan adanya stress akademik yang terjadi pada mahasiswa yang sedang mengalami ujian. Stress akademik biasanya berhubungan dengan ketakutan tidak lulus ujian, tekanan waktu (belajar yang mepet dengan waktu), ketakutan financial (tidak bisa membayar kuliah).

Populasi dalam penelitian ini adalah seluruh mahasiswa tingkat I prodi Keperawatan Tasikmalaya Jurusan Keperawatan Poltekkes Kemenkes Tasikmalaya. Pengambilan sampel dilakukan dengan menggunakan teknik total sampling, sebanyak 80 orang. Analisis data yang digunakan berupa analisis univariat.

Dari hasil estimasi interval dapat disimpulkan bahwa $95 \%$ diyakini bahwa rerata umur mahasiswa adalah 18.18 sampai dengan 18.47 tahun. 
Tabel 1. Distribusi responden menurut umur dan tekanan darah selama praktik KDM di laboratorium

\begin{tabular}{ccccc}
\hline Variable & Mean & SD & Min-maks & $95 \% \mathbf{C l}$ \\
\hline Umur & 18.33 & 0.671 & $17-20$ & $18.18-18.47$ \\
\hline TD systole & 113.25 & 13.574 & $80-160$ & $110.23-116.27$ \\
\hline TD diastole & 74.88 & 8.112 & $60-100$ & $73.07-76.68$ \\
\hline
\end{tabular}

Hasil analisis didapatkan rerata TD systole selama praktik KDM mahasiswa adalah $113.25 \mathrm{mmHg}(95 \% \mathrm{Cl}: 110.23-$ 116.27), dengan standar deviasi 13.574 . Sistole terendah $80 \mathrm{mmHg}$ dan tertinggi 160 $\mathrm{mmHg}$. Dari hasil estimasi interval dapat disimpulkan bahwa $95 \%$ diyakini bahwa systole selama praktik KDM mahasiswa adalah 110.23 sampai dengan 116.27.
Hasil analisis didapatkan rerata TD diastole selama praktik KDM mahasiswa adalah $74.88 \mathrm{mmHg}$ (95 \% Cl: 73.07 76.68), dengan standar deviasi 8.112. Sistole terendah $60 \mathrm{mmHg}$ dan tertinggi 100 $\mathrm{mmHg}$. Dari hasil estimasi interval dapat disimpulkan bahwa $95 \%$ diyakini bahwa diastole selama praktik KDM mahasiswa adalah 73.07 sampai dengan76.68.

Tabel 2. Distribusi responden menurut umur dan tekanan darah sebelum ujian KDM di laboratorium

\begin{tabular}{ccccc}
\hline Variable & Mean & SD & Min-maks & $\mathbf{9 5} \% \mathbf{C l}$ \\
\hline Umur & 18.34 & 0.655 & $17-20$ & $18.19-18.48$ \\
\hline TD systole & 116.75 & 12.094 & $100-150$ & $114.06-119.44$ \\
\hline TD diastole & 76.50 & 9.56 & $60-100$ & $74.37-78.63$ \\
\hline
\end{tabular}

Pada tabel 2., hasil analisis didapatkan rerata umur mahasiswa adalah 18.34 tahun (95 \% Cl: 18.19 - 18.48), dengan standar deviasi 0.655 tahun. Umur termuda 17 tahun dan umur tertua 20 tahun. Dari hasil estimasi interval dapat disimpulkan bahwa $95 \%$ diyakini bahwa rerata umur mahasiswa adalah 18.1 sampai dengan 18.48 tahun.

Hasil analisis didapatkan rerata TD systole sebelum ujian praktik KDM mahasiswa adalah $116.75 \mathrm{mmHg}(95 \% \mathrm{Cl}$ : 114.06 - 119.44), dengan standar deviasi 12.094. Sistole terendah $100 \mathrm{mmHg}$ dan tertinggi $150 \mathrm{mmHg}$. Dari hasil estimasi interval dapat disimpulkan bahwa $95 \%$ diyakini bahwa systole sebelum ujian praktik KDM mahasiswa adalah 114.06 sampai dengan 119.44 .

Hasil analisis didapatkan rerata TD diastole sebelum ujian praktik KDM mahasiswa adalah $76.50 \mathrm{mmHg}(95 \% \mathrm{Cl}$ : 74.37 -78.63), dengan standar deviasi 9.56. Sistole terendah $60 \mathrm{mmHg}$ dan tertinggi 100 $\mathrm{mmHg}$. Dari hasil estimasi interval dapat disimpulkan bahwa $95 \%$ diyakini bahwa diastole sebelum ujian praktik KDM mahasiswa adalah 74.37 sampai dengan 78.63.

Tabel 3. Distribusi reponden menurut jenis kelamin

\begin{tabular}{ccc}
\hline Jenis kelamin & Jumlah & Persentase (\%) \\
\hline Laki- laki & 30 & 37.5 \\
Perempuan & 50 & 62.5 \\
\hline Total & 80 & 100 \\
\hline
\end{tabular}


Distribusi jenis kelamin responden pada umumnya adalah perempuan sebanyak 50 orang $(62.5 \%)$.

Tabel 4. Distribusi reponden menurut asal sekolah

\begin{tabular}{ccc}
\hline Jenis kelamin & Jumlah & Persentase (\%) \\
\hline SMU & 60 & 75 \\
MAN & 11 & 13.8 \\
SMK & 9 & 11.3 \\
\hline Total & 80 & 100 \\
\hline
\end{tabular}

Distribusi asal sekolah responden pada umumnya adalah berasal dari SMU 60 orang (75\%).

Tabel 5. Distribusi reponden menurut tingkat kecemasan selama praktik KDM di laboratorium

\begin{tabular}{ccc}
\hline Tingkat kecemasan & Jumlah & Persentase (\%) \\
\hline Kecemasan berat & 58 & 72.5 \\
Kecemasan sedang & 22 & 27.5 \\
Kecemasan ringan & 0 & 0 \\
\hline Total & 80 & 100
\end{tabular}

Distribusi tingkat kecemasan selama praktik KDM di laboratorium responden pada umumnya adalah berada pada tingkat kecemasan berat sebanyak 58 orang (72.5\%).

Tabel 6. Distribusi reponden menurut tingkat kecemasan sebelum ujian praktik KDM di laboratorium

\begin{tabular}{ccc}
\hline Tingkat kecemasan & Jumlah & Persentase (\%) \\
\hline Kecemasan berat & 67 & 83.75 \\
Kecemasan sedang & 13 & 16.25 \\
Kecemasan ringan & 0 & 0 \\
\hline Total & 80 & 100 \\
\hline
\end{tabular}

Distribusi tingkat kecemasan sebelum ujian praktik KDM di laboratorium responden pada umumnya adalah berada pada tingkat kecemasan berat sebanyak 67 orang (83.75\%).

\section{PEMBAHASAN}

Hasil penelitian ini menunjukkan bahwa rerata tekanan darah systole selama praktik KDM di laboratorium $113.25 \mathrm{mmHg}$ dan rerata tekanan darah diastole selama praktik KDM di laboratorium $74.88 \mathrm{mmHg}$. Sedangkan rerata tekanan darah systole sebelum ujian praktik KDM di laboratorium $116.75 \mathrm{mmHg}$ dan rerata tekanan darah diastole selama praktik KDM di laboratorium
$76.50 \mathrm{mmHg}$. Jika dilihat dari hasil pengukuran tekanan darah systole dan diastole selama praktik dan sebelum ujian praktik KDM di laboratorium, maka dapat dilihat terjadi peningkatan diastole sebesar $3.5 \mathrm{mmHg}$ dan diastole $1.72 \mathrm{mmHg}$. Walaupun secara angka, peningkatannya tampak tidak siginifikan, namun terdapat peningkatan tekanan darah baik sistol dan 
diastole sebelum ujian praktik KDM di laboratorium.

Peningkatan tekanan darah baik sistol dan diastole saat akan melaksanakan ujian diindikasikan sebagai salah satu pemicu stress. Hal ini sesuai dengan hasil penelitian yang dilakukan oleh Gaya et all (2014) yang menyatakan bahwa hasil penelitiannya menunjukkan bahwa mahasiswa yang sedang menjalani seminar presentasi pada ujian akhir mengalami stress akademik yang ditunjukkan dengan peningkatan tekanan darah dan level prolaktin. Stress akademik dapat menjadi salah satu penyebab stress. $\mathrm{Hal}$ ini ditunjukkan dengan adanya peningkatan tekanan darah dan level prolaktin. Peningkatan tekanan darah dan prolaktin menjadi salah satu implikasi dari fisiopatologis akibat koneksi neuroendokrin dari respons individu terhadap stress.

Hasil penelitian yang dilakukan oleh Kavitha (2011) menunjukkan hasil yang sama. Kavitha melakukan penelitian pada mahasiswa FK USU angkatan 2008. Hasil penelitiannya diperoleh bahwa terdapat perubahan tekanan darah sistol dan diastole sebelum ujian. Hasil uji korelasi menunjukkan hubungan yang kuat bagi tahap stress dan perubahan tekanan darah.

Tekanan darah tinggi (hipertensi) masih menjadi permasalahan utama di bidang kesehatan saat ini. Di negara lain berbagai upaya pendeteksian, pencegahan, dan penatalaksanaan hipertensi sudah banyak dilakukan. Walaupun penyebab hipertensi belum diketahui secara pasti, namun ada beberapa factor risiko terjadinya hipertensi seperti obesitas, stress atau penuaan atau kombinasi dari ketiganya menjadi penyebab hipertensi (Rohman, dkk, 2011). Situasi stress akan melepaskan hormone stress yang akan menyempitkan pembuluh darah dan mempercepat detak jantung sehingga tekanan darah akan meningkat. Namun kondisi tekanan darah yang meningkat akibat stress ini akan normal kembali ketika stress sudah menghilang.

Hasil penelitian ini pun menunjukkan bahwa mahasiswa yang akan melaksanakan ujian praktik KDM di laboratorium masuk ke dalam kriteria berat $(83,75 \%)$. Penelitian Suyamto, Prabandari, dan Marchira (2009) menunjukkan hasil bahwa skor kecemasan mahasiswa menjelang ujian akhir program pre test pada kelompok perlakuan dan kelompok kontrol umumnya termasuk ke dalam kategori sedang. Hal ini menunjukkan bahwa mahasiswa yang akan atau sedang menjalani ujian, ketika dilakukan pengukuran tingkat kecemasan umumnya menunjukkan tingkat kecemasan sedang atau bahkan tinggi.

Rasa cemas terjadi pada saat adanya kejadian atau peristiwa tertentu, maupun dalam menghadapi suatu hal. Bahkan kecemasan ini perlu dimiliki oleh manusia. Apabila cemas berlebihan maka akan berubah menjadi abnormal, ketika kecemasan yang ada dalam diri individu menjadi berlebihan atau melebihi dari kapasitas umumnya. Individu yang mengalami gangguan seperti ini bisa dikatakan mengalami gangguan cemas yaitu ketakutan yang berlebihan dan sifatnya tidak rasional.

Datangnya cemas tidak terduga tergantung dari stresor yang mempengaruhi. Cemas sering terjadi oleh para mahasiswa diantaranya ketika mahasiswa akan menghadapi situasi yang sulit atau keadaan yang dirasakan sangat mengganggu ketenangannya. Beberapa keadaan yang membuat mahasiswa sering merasa tidak nyaman atau cemas adalah banyaknya tugas, serta beban tugas kuliah yang sangat berat. Mahasiswa keperawatan sering terkena cemas dan stress selama menempuh pendidikan keperawatan termasuk saat mahasiswa akan melaksanakan ujian praktik keperawatan di laboratorium.

Lingkungan belajar mahasiswa tingkat I secara umum berubah dari tingkat SMU ke tingkat pendidikan D III Keperawatan. Mahasiswa banyak dituntut untuk terampil melakukan suatu tindakan keperawatan, selain diperlukan juga tingkat kognitif dan afektifnya. Namun perubahan tersebut dapat 
menimbulkan kecemasan bagi mahasiswa jika dia tidak siap mengikuti perubahan tersebut. Hal ini dapat menyebabkan kebingungan dan perubahan persepsi seseorang. Perubahan persepsi ini dapat menyebabkan penurunan kemampuan memusatkan perhatian, menurunkan daya ingat seseorang, mengganggu kemampuan menurunkan menghubungan satu hal dengan hal yang lain (Kaplan dan Saddock, 2005 dalam Widosari, 2010). Ujian langsung yang berhadapan antara penguji dan teruji juga bisa meningkatkan kecemasan (Stowell \& Bennett, 2010). Mahasiswa berubah menjadi grogi, bahkan lupa terhadap apa yang telah dipelajarinya walaupun persiapan melaksanakan ujian telah dilakukan.

Pengalaman seseorang dalam melaksanakan ujian juga merupakan factor lain dalam yang dapat mempengaruhi kemampuan belajar mahasiswa. Mahasiswa yang pernah mengikuti ujian sebelumnya, cenderung mampu melakukan ujian berikutnya dengan baik (Chamberlain, Daly, Spalding, 2011). Hal ini dapat meningkatkan hasil atau prestasi belajar mahasiswa. Factor lain yang dapat mempengaruhi keberhasilan akademis mahasiswa secara

\section{KESIMPULAN}

Rerata TD systole selama praktik KDM mahasiswa adalah $113.25 \mathrm{mmHg}(95 \% \mathrm{Cl}$ : 110.23-116.27). Rerata TD diastole selama praktik KDM mahasiswa adalah 74.88 mmHg (95\% Cl: 73.07 -76.68)

Rerata TD systole sebelum ujian praktik KDM mahasiswa adalah $116.75 \mathrm{mmHg}$ (95\% Cl: 114.06-119.44). Rerata TD diastole sebelum ujian praktik KDM mahasiswa adalah $76.50 \mathrm{mmHg}(95 \% \mathrm{Cl}$ : 74.37-78.63).

\section{SARAN}

Mahasiswa sebaiknya lebih mempersiapkan diri sebelum melaksanakan ujian praktik di laboratorium baik mata kuliah KDM ataupun mata kuliah lainnya. Hal ini ditujukan agar langsung adalah tingkat kepercayaan diri dan hasil uji kecemasan dapat berdampak secara langsung (Abdi, H. M.; Bageri, S.; Shoghi, S.; goodarzi, Sh.; Hosseinzadeh, A, 2012). Sehingga jika mahasiswa tidak dapat meningkatkan keberhasilan akademik, maka mahasiswa tersebut cenderung akan mengalami stress.

Stress merupakan kondisi psikis yang disebabkan oleh berbagai perasaan negative terhadap suatu hal. Contohnya adalah rasa takut, khawatir, cemas, tertekan, merasa tidak aman. Perasaanperasaan negative tersebut merupakan hasil dari olah pikiran negative yang ada dalam diri seseorang. Saat seorang mahasiswa stress karena ujian, berbagai perasaan negative saling campur aduk di dalam benaknya. Cemas jika tidak dapat mengerjakannya dengan baik, takut bila tidak lulus dalam menghadapi ujian tersebut. Salah satu cara untuk menghilangkan rasa cemas tersebut adalah menghilangkan ketakutan yang ada. Caranya adalah dengan meyakinkan diri bahwa telah siap, dengan cara belajar dengan baik dan berdoa agar hasilnya pun baik pula.

Distribusi tingkat kecemasan selama praktik KDM di laboratorium responden pada umumnya adalah berada pada tingkat kecemasan berat sebanyak 58 orang (72.5\%). Distribusi tingkat kecemasan sebelum ujian praktik KDM di laboratorium responden pada umumnya adalah berada pada tingkat kecemasan berat sebanyak 67 orang $(83.75 \%)$.

mahasiswa lebih siap lagi dalam menghadapi ujian sehingga tidak mengalami cemas yang berlebihan dan tidak terjadi peningkatan tekanan darah. 


\section{REFERENSI}

Abdi, H. M.; Bageri, S.; Shoghi, S.; goodarzi, Sh.; Hosseinzadeh, A. (2012). The Role of Metacognitive and Self-Efficacy Beliefs in Students' Test Anxiety and Academic Achievement. Australian Journal of Basic \& applied sciences. Nov 2012, Vol. 6 Issue 12, p418-422. $5 p$

Anandarajan B., Kouser Banu, Muthukumar S., Gajanan G. Atram. (2013). Professional examination stress induced hemodynamic changes in first year MBBS students. International journal of biomedical and advance research. vol 4, no 11.

Chamberlain, Suzzane., Daly, Anthony., Spalding, Victoria. (2011). The fear factor: student's experience of test anxiety when taking a level examinations. Pastoral Care in Education: An International Journal of Personal, Social and Emotional Development. Volume 29, Issue 3 , 2011

Gaya, Bako Ibrahim, et all. (2014). The effect of prolactin in response to academic stress during examination condition in healthy male and female university students. American Journal of BioScience. Vol. 2, No. 1, 2014, pp. 1-4. doi: 10.11648/j.ajbio.20140201.11

Kavitha, Kandasamy. (2011). Hubungan stress ujian dengan perubahan tekanan darah pada mahasiswa Fakultas Kedokteran Universitas Sumatera Utara (FK USU) Angkatan 2008 pada tahun $2010 . \quad$ Diunduh dari repository.usu.ac.id/handle/123456789/ 21565 pada tanggal 27 Januari 2015.
Mohler, Marie Elaine. (2013). Utilization of Emotional Freedom Techniques (EFT) to reduce test anxiety in high stakes testing. diakses 22 Mei 2014 dari http://gradworks.umi.com/35/87/358744 3.html. 258 pages; 3587443 proquest dissertations \& theses.

Rohman, Mohammad Saifur, dkk. (2011). Pemahaman dokter Indonesia mengenai hipertensi dan permasalahan yang dihadapi pada praktik sehari- hari. Maj Kedokt Indon, Volum: 61, Nomor: 2, Februari 2011.

Stowell, Jeffrey., Bennett, Dan. (2010). Effects of online testing on student exam performance and test anxiety. Journal of educational computing research. Volume 42, Number 2 / 2010

Suliswati. (2005). Konsep Dasar Keperawatan Kesehatan Jiwa. Jakarta: EGC.

Suyamto, Prabandari, Yayi Suryo., Marchira, Carla Raymondalexas. (2009). Pengaruh Relaksasi Otot Dalam Menurunkan Skor Kecemasan T-Tmas Mahasiswa Menjelang Ujian Akhir Program Di Akademi Keperawatan Notokusumo Yogyakarta. Berita Kedokteran Masyarakat. Vol. 25, No. 3, September 2009. halaman 142 - 149

Widosari, Yuke Wahyu. (2010). Perbedaan derajat kecemasan dan depresi mahasiswa kedokteran pra klinik dan ko-asisten di FK UNS Semarang. Diunduh tanggal 21 Mei 2014 dari http://eprints.uns.ac.id/3185/1/1684106 09201010551.pdf 